\title{
Spatio-Temporal Distribution of Rural Markets in Bekwarra Local Government Area of Cross River State of Nigeria
}

\author{
Ochiche C. Abua [M. Sc], Ajake A. O. [PhD], Okpilia, F. I [PhD] \\ Dept of Geography and Environmental Science University of Calabar, Nigeria. \\ Dept of Geography and Environmental Science University of Calabar, Nigeria. \\ Dept of Geography and Environmental Science University of Calabar, Nigeria.
}

\begin{abstract}
The study of spatio-temporal distribution of rural markets in Bekwarra Local Government Area of Cross River State of Nigeria was conducted to identify and explain the order that exist in the pattern of distribution of rural markets in space, time and function as well as commodities offered for sale and the spheres of influence of markets in the area. Data used for this research were obtained from field observation, measurements and questionnaire interviews. A total of 472 persons were interviewed in the eleven markets covered in the study. Data collected were presented in tables and maps. The hypothesis on the spatial distribution of markets was tested using nearest neighbor statistics while the one on the difference between mean distances of same-day markets and adjacent-day markets was tested using students t-test. The outcome of the study shows that markets in Bekwarra Local Government Area are randomly distributed. Same-day markets were found to be more widely spaced than adjacent-day markets. All markets adopt a 5-day periodicity regime and fall under two temporal cycles. Three classes of markets were identified; local, state and national markets. Agricultural produce and local craft products are the major commodities offered for sale in the markets. The paper recommends spatial re-organization of market centers to enhance their viability and to remove unhealthy competition for patronage.
\end{abstract}

Keyword: Distribution, Functional, Rural Markets, Spatial, Temporal.

\section{Introduction}

Environmental resource planners have for long been pre-occupied with providing explanation to the order that exist in the pattern and distribution of phenomena on the earth's surface. The task here is to describe and explain the order that exist in the way features are arranged in space [1]. Rural market centers, which operate as central places, are very appropriate examples since their distribution and spatial interaction clearly reveal the functioning of economic systems and the processes of change in the space economy. Market centers are by far the commonest features of commercial manifestation in rural areas. They are found in all countries of the world. They operate in both open and built-up spaces for exchange of commodities, especially the sale and purchase of agricultural produce and manufactured goods.

In rural communities, markets are largely periodic in the sense that they are not open for trade every day. Market activities take place once in a market week. A market week is the number of days between a market day and the next in a particular community. On such market days there are generally a large number of sellers and buyers. Among the set of sellers are itinerant traders and part-time traders.

Numerous studies undertaken on the nature of rural markets in Nigeria has revealed very interesting features. The work of Hodder and Ukwu[2] and others can testify to this. Although many studies on rural markets in Nigeria have produced key generalizations, studies in Eastern Nigeria have not been exhaustive given the heterogeneous nature of space economy. There is also inadequate information on market origin, socioeconomic and demographic characteristics of market attendants, spatio-temporal distribution of rural markets, organization of market centers, pricing system and land-use pattern around the markets centers. At the moment, there is no documented work on rural market centers in Bekwarra Local Government Area.

The importance of the study of rural markets centers cannot be over-emphasized. Sound planning and development of market centers depend on the processes that led to the emergence of market centers. Market patronage relies so much on the knowledge of the spatial distribution of the available market centers as well as the commodities offer for sale. Thus, the study will therefore be useful in the following ways;

1 providing knowledge of the location and function of rural markets centers in the study area.

2 providing a better understanding of regional specialization and the type of goods and services available in specific rural markets.

3 assisting policy makers in the formulation of relevant policies and programmes that will enhance social and economic development of rural areas

4 exposing the contributions which the rural areas are making in regional and inter-regional trade in Nigeria. 


\subsection{The Study Problem}

Two attributes that are common among rural markets are their periodicity and location pattern. These attributes represent the temporal and spatial characteristics of rural markets respectively. Bekwarra Local Government Area has eleven markets. The region operates a 5-day market week with each settlement having four market-less days. It is expected that by competing for threshold population, the markets should exhibit some form of order in their spatial and temporal distribution. Not only do markets compete both in space and time for threshold population, they perform different functions for which they should also be some order in their distribution.

The problem, however, is in identifying the order that exist in the location pattern and functions of periodic markets in Bekwarra Local Government Area. Other problems to be considered are market sphere of influence and the type of goods and services offered for sale in each market. In order to find solution to these problems, the following research questions are formulated;

1 Is there any order in the distribution of markets in space and time in the study area? If there is, what is the nature of the order? How does this order conform to, or differ from any known order in a similar or different environment? How does this order affect market viability?

2 Are there market cycles in the study area?

3 What type of goods and services are offered for sale in Bekwarra markets?

4 Do markets in Bekwarra Local Government Area have clearly defined catchment areas?

5 Is there any functional hierarchy in the distribution of rural markets in Bekwarra?

\subsection{Objective of the Study}

The essence of the study is to identify the order that exist in the pattern of distribution and function of periodic markets in Bekwarra Local Government Area of Cross River State, Nigeria. Specifically, the study is aimed at achieving the following objectives;

1. To identify and evaluate the order that exists in the spatial and temporal distribution of rural markets in Bekwarra Local Government Area.

2. To find out whether market cycles or rings exist in the study area.

3. To examine the types of goods and services offered for sale in Bekwarra markets.

4. To delineate market catchment areas in Bekwarra.

5. To order markets in the study area according to their sphere of influence.

6. To suggest a strategy for proper market planning.

\subsection{Research Hypothesis}

There exist a definite pattern both in time and space in the distribution of rural markets in Bekwarra Local Government Area.

\subsection{The Study Area}

Bekwarra Local Government Area, the field of study was created out of the then Ogoja Local Government Area of Cross River State, Nigeria in 1996. It lies at the north-eastern corner of Cross River State between longitudes 848 " and 9 east of the Greenwich meridian and latitudes 637 " and 647 " north of the equator. It covers a landmass of approximately 345 square kilometers [3] and shares boundaries with Vandikya Local Government of Benue State in the north, Ogoja Local Government Area in the south, Obudu Local Government Area in the east and Yala Local Government Area in the west. The Local Government area has sixteen clans which spread over ten political wards.

Bekwarra Local Government Area is made up of two ethnic groups-Bekwarra and Afrike. The dominant tribe is Bekwarra with over $70 \%$ of the entire population. The spoken languages are almost similar in linguistic characteristics [3]. According to the 2006 population census, Bekwarra Local Government Area has a population of 105,822 inhabitants.

Agriculture is the main stay of the economy of Bekwarra people as over $80 \%$ of the population is engaged in it. Some of the agricultural produce are yams, beans, guinea corn, millet, cassava, maize, pepper, groundnut, palm oil and kernel, rice, vegetable, melon, banana, plantain, oranges, palm wine and three- leave yams. Other products are fishes and bush meat. Manufactured items from local craft industries include mortar, pestle, baskets, hand fan, local armchairs, gari sieves, brooms, talking drum and wooden gung. These products serve as commodities for sale in the eleven markets of the local government area. These market centers provide avenue for the assemblage and bulking of goods for their onward movement along the chain of distribution.

\section{Theoretical Framework/Literature Review}

The study of the spatial, temporal and functional distribution of rural markets in Bekwarra is rooted in the Central Place Theory of Walter Christaller propounded in 1933[4]. The theory is very useful in providing the 
method and procedures for investigating the organized relationship and function of an economic system from the spatial view point. According to Christaller, if central places (settlements, markets, and so on) exist for the purpose of supplying goods and services to neighbouring areas, then there should be a hierarchy in the distribution of central places. Such hierarchy in central places range from higher order central places to lower order places. Higher order central places perform higher order functions and contain a wide variety of goods and services than lower order central places [5].

The theory assumes that both the suppliers and consumers wish to derive the greatest economic benefits from their market decision in the retailing of goods and services. The supplier would like to maximize profit while the consumer would like to minimize cost.

The theory was built on the concepts of range and threshold of goods and services. The range of a good or service is the furthest distance the dispersed population is willing to go in order to purchase such good and service offered for sale at a market place at a given price while the threshold refers to the minimum level of demand necessary to support a business activity or the condition for market entry. The range of a good, therefore, delineates the market area or catchment area or central place for the central goods while the threshold population is the area below which the central place cannot supply a market good at a break-even profit. Below the threshold, sales will be too few for firms to earn economic profit [6]. Since market centers are involved in direct competition for patronage both in space and time, it is expected that market centers should exhibit uniform pattern of distribution [7].

Base on the central place theory, this research is undertaken to ascertain the effect of market competition both in space and time for patronage on the distribution of rural markets in Bekwarra Local Government Area.

Periodic or temporal markets are markets that perform their marketing activities and operations on time schedules. They are weekly in organization rather than daily. The importance

of rural markets as centers for exchange of goods, services, ideas and fashion as well as initiating and encouraging economic, social and political development is obvious. Rural markets make possible the exploitation of the resources, which may have limited or no value in the local communities [8]. It is through rural markets that most agricultural and cottage industrial products first enter the exchange economy and to attempt any analysis of economic activities in these areas without reference to rural market centers and local exchange is to ignore those institutions and processes of most immediate and vital concern to the bulk of the population [2].

Attempt have been made to classify the theories of origin of periodic markets into two [9]. The first was the orthodox theory approach which views the origin of periodic markets from man's inherent tendency and propensity to barter while the second theory links the origin of periodic markets to long distance or external trade. Stine suggested that the guiding word for the need for periodicity could be summarized by the concept of "threshold" and "range" of goods and services [10]. Periodicity of rural markets has been attributed to low level of income in developing economies [11]. This attribute permits the concentration of sales on relatively short time and extent. Adalemo also argued that the periodic nature of rural markets might evolve with settlement pattern, which will be to different settlers having or operating on different periodicities [12]. Lack of storage facilities and low population concentration are responsible for market periodicity. These factors do not support continuous trading and therefore markets are forced to hold periodically in the rural areas [13].

It is believed that periodic markets result from and persist because of the need of producers, the organization of time, inertia and comparative advantage. This institution had to be coordinated with a calendar defined with the routine of production, religion, administration, rest and recreation.

Available literature on rural markets reveals variations in market periodicities. Different ethnic nations have different periodic regimes or market calendar/weeks. In Nigeria, different market calendars have been noted. Hodder and Ukwu identified a 2-day, 4-day and 8-day periodicities in Yorubaland and a 4-day, 8-day and 21-day periodicities in Ibo land [2]. Hill and Smith observed a seven day market week in almost all parts of Northern Nigeria [14]. A 2-day periodic market has one market-less day, 4-day market has three, 5-day market has four and so on.

Another relevant feature of rural markets is the linkage of these markets into a ring or cycle that reflects the rotation of markets days among a set of market places. A market ring is an integrated sequence of markets that follow a particular temporal regime. This integrated timing and pattern of market has been described by Hodder as logical and convenient. He referred to market cycle as an indigenous phenomenon expressing an intelligent mutual self-interest among neighbouring village chiefs or "bale". A ring cycle of market meeting expresses the need to contact a wider and more varied section of people and goods that is impossible when only one market is involved. Whether market cycles are as tightly organized as has been suggested [13] remains a matter to the debated. Marshall has argued that they should be regarded more as relative than absolute entities while Ukwu warned that the concept of the marketing ring must be applied with 
caution since it suggests an institutionalized order and a uniformity which may not exist [2]. For the area unit as a whole, the ring is meaningful only as indicating the markets most frequently visited by the people in that unit.

\section{Spatio-Temporal Distribution of Rural Markets}

According to Hudson a location pattern may arise from either a contagious process or repulsive process [15]. A contagious process leads to the clustering together of units to produce an agglomerated order of market distribution. A repulsive process or competitive process is one which when given appropriate topographic and population distribution in an area will result in a uniform or maximally spaced order of distribution. Several studies have shown that periodic market in rural space exhibit an even order of distribution since they are directly engaged in spatial and temporal competition.

The Nearest Neighbour Statistics of the form:

$$
\mathrm{Rn}=2 \mathrm{~d}
$$

Where $\mathrm{Rn}=$ Nearest Neighbour Value

$\mathrm{d}=$ Average Neighbour Intermarket Distance

$\mathrm{n}=$ Number of Markets Investigated

$\mathrm{a}=$ Area of Study Location

has been used to test the spatial distribution of periodic markets in many areas. A study of four-day market periodicity in Western Nigeria has shown that the spatial patterns of markets operating on each of the four days were significantly different from random and were approaching uniformity [16]. Other places where uniform spatial distributions of rural markets have been observed include former Katsina Emirate [14], Ghana [17], Kenya $[18,19]$ and Akwa Ibom State, Nigeria [20].

In terms of temporal-locational spacing of rural market or spatio-temporal synchronization hypothesis, it has been observed that same-day markets are more widely spaced than adjacent-day markets $[16,17,18]$. This hypothesis has been investigated in several parts of Africa by measuring distances separating same-day markets and adjacent day markets. The means of these two set of measurements are then tested for significant difference using the students' t-test.

Hodder suggested that the basic pre-condition for the location of a market seems to be a threshold population density of about 50 persons per square mile. He made this observation in the thickly populated areas of Yorubaland where periodic markets are distributed fairly evenly at distance from each other averaging 7.2 miles $(11.52 \mathrm{~km})[13]$.

Classification of rural markets based on their functions as central places is normally approached through the analysis of specific information concerning the type of goods and services available and the size and nature of the area served by the market. Observation and interviews (either oral or through the use of questionnaires) are used to analyze and classify markets based on the number of functions. Using observation and interview techniques, skinner identified five hierarchical markets in rural china. They are regional markets, central markets, intermediate markets, standard markets and minor markets [21].

\section{Research Methodology}

The first step taken in the study of spatio-temporal distribution of rural markets in Bekwarra Local Government Area was to undertake a reconnaissance visit to all the eleven markets in the study area. The aim was to obtain first hand information on market location, range of goods and services available and market administration. This familiarization visit was also meant to get the researcher acquainted with the natural environment, the market population and to determine the appropriate sampling techniques for data collection.

The data needed to achieve the objectives of the study include; the number of markets and their locations as well as their frequency of meeting, inter-market distances, the population of each market, the range of commodities (their source and destination) and the sphere of influence of each market. These data were generated mainly from the field (market), clan heads, market administrators, buyers, sellers, market associations and maps. Inter-market distances were calculated as the crow flies using the map of Bekwarra Local Government Area on a scale of 1:100000. Buyers and sellers questionnaires were designed to obtain data on the place of origin of buyers and sellers, source and destination of commodities bought and sold, frequency of market visit and markets most frequently visited. A total of 472 persons responded to the structured questionnaires. No definite number of respondents per market was set, instead the administration of questionnaires dependent on the population size of each eleven market and availability of each set of respondents. The questionnaires were administered directly to the respondents by the researcher and four trained field assistants.

Data collected were presented in tables either as absolute frequencies, percentages or ratios. The hypothesis on spatial distribution of markets was tested using nearest neighbour statistics while the one on spatio-temporal distribution was tested using student's t-test. 


\section{Data Presentation, Analysis And Discussion}

It was discovered that the average straight-line distance between markets in Bekwara is $4.1 \mathrm{~km}$. However, this varies from $1.8 \mathrm{~km}$ between Abuochiche and Abuagbor markets to as high as $20 \mathrm{~km}$ between Afrike II and Gakem markets. Average road distance between markets is $4.5 \mathrm{~km}$ which is much higher than the straight-line distance. The spatial distribution of market was found to be random (see TABLE 2). Nine out of the eleven markets in Bekwara are located on road junctions while the remaining two are roadside markets (see fig $1)$.

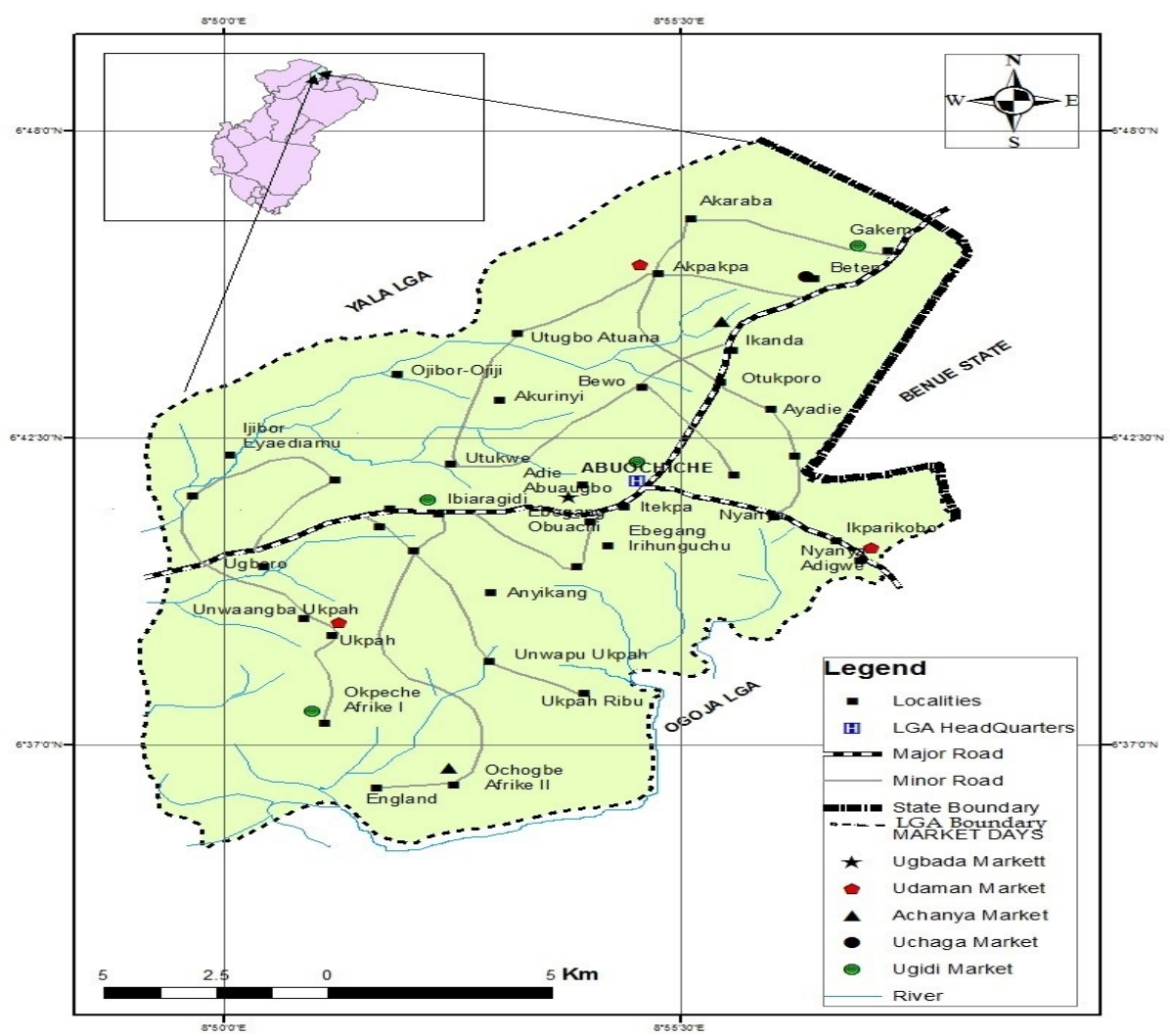

Fig. 1: Spatio-Temporal Distribution of Rural Periodic Markets in Bekwarra Local Government Area of Cross River State, Nigeria.

Table 1: Inte-rmarket Distances as the Crow Flies (Km)

\begin{tabular}{|c|c|c|c|c|c|c|c|c|c|c|c|}
\hline & 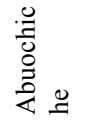 & 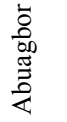 & 总 & $\begin{array}{l}\exists \\
\frac{0}{3} \\
\frac{3}{4}\end{array}$ & $\begin{array}{l}\frac{\pi}{0} \\
\frac{\tilde{a}}{\pi} \\
\frac{\tilde{z}}{4}\end{array}$ & $\stackrel{\Xi}{ \pm}$ & $\begin{array}{l}\text { हี } \\
\text { 氙 }\end{array}$ & 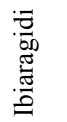 & 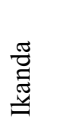 & 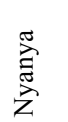 & $\begin{array}{l}\frac{a}{\tilde{T}} \\
\frac{0}{5}\end{array}$ \\
\hline Abuochiche & 0 & 1.8 & 11.5 & 12.0 & 8.0 & 6.5 & 7.0 & 3.5 & 5.5 & 5.0 & 8.5 \\
\hline Abuagbor & 1.8 & 0 & 10.0 & 11.0 & 8.5 & 6.8 & 8.0 & 4.0 & 6.0 & 5.5 & 9.0 \\
\hline Afrike I & 11.5 & 10.0 & 0 & 3.5 & 18.0 & 16.0 & 19.0 & 10.0 & 15.5 & 14.0 & 4.0 \\
\hline Afrike II & 12.0 & 11.0 & 3.5 & 0 & 20.0 & 17.0 & 20.0 & 11.0 & 16.0 & 12.0 & 6.0 \\
\hline Akpakpa & 8.0 & 8.5 & 18.0 & 20.0 & 0 & 5.0 & 7.0 & 9.0 & 6.0 & 13.0 & 19.0 \\
\hline Beten & 6.5 & 6.8 & 16.0 & 17.0 & 5.0 & 0 & 3.0 & 12.0 & 3.0 & 10.0 & 17.0 \\
\hline Gakem & 7.0 & 8.0 & 19.0 & 20.0 & 7.0 & 3.0 & 0 & 14.0 & 5.0 & 11.0 & 19.0 \\
\hline Ibiaragidi & 3.5 & 4.0 & 10.0 & 11.0 & 9.0 & 12.0 & 14.0 & 0 & 9.0 & 8.0 & 8.0 \\
\hline Ikanda & 5.5 & 6.0 & 15.0 & 16.0 & 6.0 & 3.0 & 5.0 & 9.0 & 0 & 8.0 & 14.0 \\
\hline Nyanya & 5.0 & 5.5 & 14.0 & 12.0 & 13.0 & 10.0 & 11.0 & 8.0 & 8.0 & 0 & 12.0 \\
\hline Ukpah & 8.5 & 9.0 & 4.0 & 6.0 & 19.0 & 17.0 & 19.0 & 8.0 & 14.0 & 12.0 & 0 \\
\hline
\end{tabular}

Source: Field Survey Data

Table 2 : Nearest Neighbour Intermarket Distances

\begin{tabular}{|l|l|}
\hline Market & Nearest Neighbour Intermarket Distance $($ Km $)$ \\
\hline Abuagbor & 1.8 \\
\hline Abuochiche & 1.8 \\
\hline Afrike 1 & 3.5 \\
\hline Afrike 2 & 3.5 \\
\hline Akpakpa & 5.0 \\
\hline
\end{tabular}




\begin{tabular}{|l|l|}
\hline Beten & 3.0 \\
\hline Gakem & 3.0 \\
\hline Ibiaragidi & 3.5 \\
\hline Ikanda & 3.0 \\
\hline Nyanya & 5.0 \\
\hline Ukpah & 4.0 \\
\hline Average Inter market Distance(d) & 3.4 \\
\hline Area of Study Location(a) & $345 \mathrm{~km} 2$ \\
\hline Nearest Neighbour Value(Rn) & 1.214 (random distribution) \\
\hline
\end{tabular}

Source: Field Survey Data

All the eleven markets in the local government area have 5-day market periodicity as each market holds once every five days. These market days are Ugidi, Achanya, Udama, Ugbada and Uchaga. The distribution of these markets among the five market days are shown in TABLE 3.

Table: Frequency of market holding on days of the week in Bekwarra

\begin{tabular}{|l|l|l|l|}
\hline S/N & Market Day & No. of Market Holding & Settlement(s) \\
\hline 1 & Ugidi & 4 & Abuochiche, Gakem, Afrke1 and Ibiaragidi \\
\hline 2 & Achanya & 2 & Afrike II and Ikanda \\
\hline 3 & Udama & 3 & Akpakpa, Ukpah and Nyanya \\
\hline 4 & Ugbada & 1 & Abuagbor \\
\hline 5 & Uchaga & 1 & Beten \\
\hline
\end{tabular}

Source: Field Survey Data

From Table 3, it is expected that Ugbada and Uchaga should be unique market days as they are the only days when only one market holds. This is not so. Investigation reveals that these two markets are just local markets struggling to survive from unhealthy competition for patronage with markets from neighbouring Local Government areas that hold on the same day.

The temporal-locational spacing was also unique. Markets that hold on the same day are more widely spaced than markets that hold on adjacent days. The only exception is Ibiaragidi and Abuochiche markets. Ibiaragidi market has since decline in importance because of the unhealthy competition for patronage with Abuochiche market that holds on the same day (See fig. 1). The difference between the mean nearest neighbor inter-market distances of same-day and adjacent-day markets was tested using student's t-test. The difference was found to be significant at $5 \%$ (see TABLE 4 )

Table 4: Nearest Neighbor Inter-market Distances for Same-Day and Adjacent-day Markets(KM)

\begin{tabular}{|l|l|l|}
\hline Market & Same-day market(X1) & Adjacent-day market(X2) \\
\hline Abuochiche & 3.5 & 5.5 \\
\hline Abuagbor & 11.0 & 6.8 \\
\hline Afrike 1 & 10.0 & 3.5 \\
\hline Afrike 11 & 16.0 & 6.0 \\
\hline Akpakpa & 13.0 & 8.5 \\
\hline Beten & 18.0 & 3.0 \\
\hline Gakem & 7.0 & 5.0 \\
\hline Ibiaragidi & 3.5 & 9.0 \\
\hline Ikanda & 16.0 & 6.0 \\
\hline Nyanya & 12.0 & 5.0 \\
\hline Ukpah & 12.0 & 9.0 \\
\hline Mean & 11.1 & 6.1 \\
\hline
\end{tabular}

Source: Field Survey Data

$\mathrm{X} 1=11.1, \mathrm{X} 2=6.1, \mathrm{SD} 1=4.6, \mathrm{SD} 2=2.0$, t-calculated $=2.513$, t-table at $5 \%=2.09$.

Where $\mathrm{X} 1$ and $\mathrm{X} 2$ are the mean inter-market distances of same-day and adjacent-day markets respectively, SD1 and SD2 are the standard deviations of same-day and adjacent- day markets respectively.

Two markets cycles were observed in Bekwara LGA. One is in the North and the other in the South. The markets that make up the northern cycle include Gakem, Ikanda, Akpakpa, and Beten markets. Those that constitute the southern cycle are Abuochiche, Afrike II, Ukpah and Abuagbor markets. These cycles reflect the markets most frequently visited by buyers and sellers.

The main types and varieties of commodities traded in Bekwara markets are shown in the table below: 
Table 4:Types of commodities traded in the market.

\begin{tabular}{|l|l|}
\hline Types of commodities & Varieties \\
\hline Vegetable/spices & $\begin{array}{l}\text { Okro, pepper, banana, bush mangoes, locust bean seeds, orange, onions, } \\
\text { tomatoes, green vegetables, ginger, palm kernel, plantain and kola nut. }\end{array}$ \\
\hline Cereal, Tuber and other products & $\begin{array}{l}\text { Guinea corn, millet, maize, rice, yams, cassava, cassava flour, fermented } \\
\text { cassava, garri and sweet potatoes. }\end{array}$ \\
\hline Pulses/Legumes & Beans, cowpea, groundnuts, bean seed and melon. \\
\hline Fish & Tilapia, crayfish, mud fish, ice fish and liver fish. \\
\hline Bush meat & Antelopes, monkeys, rabbits, alligator and grass cutter \\
\hline Domestic Animals & Goats, sheep and fowls. \\
\hline Edible Oil & Palm oil and groundnut oil. \\
\hline Manufactured Goods & $\begin{array}{l}\text { Bicycle parts, beer, glasses, spoon, beverages, torch-light, batteries, sugar, } \\
\text { umbrella, hand bags, kerosene, mattress, old clothes, new clothes, cooking } \\
\text { utensils and foot wear. }\end{array}$ \\
\hline Local Craft Products & $\begin{array}{l}\text { Earthern pots, Hoe, local soap, local snuff, mats, hat, morter and pristle, chairs, } \\
\text { beds, baskets, sieves, local tray, brooms, hand fan cutlasses. }\end{array}$ \\
\hline Services & $\begin{array}{l}\text { Cooked food, bush services, motorcycle repairs, barbing, hairdressing, bicycle } \\
\text { repairs, tailoring and shoe repairs. }\end{array}$ \\
\hline
\end{tabular}

As shown in table 4, each market in Bekwara LGA traded on a wide range of commodities. The chief agricultural produced are yams, palm wine, palm oil, palm kernel, cassava, gari, fermented cassava (Akpu), rice and groundnut.

Based on the market functions, sphere of influence, and market attendance of each market, three classes of rural markets were identified. These are local, state and national markets. Local markets attract patronage from the local government area only. State markets do not only attract people from the locality but outside the LGA within the state. National markets are attended by people in the LGA, State and other parts of Nigeria.

Table IV: Classification of Rural Markets Based on Sphere of Influence, Varieties of Goods and Services in Bekwarra LGA.

\begin{tabular}{|l|l|l|l|l|l|}
\hline Market Centre & A & B & C & $\begin{array}{l}\text { Varieties of } \\
\text { Commodities }\end{array}$ & Class of Market \\
\hline Abuagbor & X & - & - & 45 & Local market \\
\hline Abuochiche & X & X & X & 77 & National market \\
\hline Afrike 1 & X & X & X & 57 & National market \\
\hline Afrike II & X & X & - & 47 & State market \\
\hline Akpakpa & X & X & - & 56 & State market \\
\hline Beten & X & - & - & 37 & Local market \\
\hline Gakem & X & X & X & 59 & National market \\
\hline Ibiaragidi & X & X & - & 41 & State market \\
\hline Ikanda & X & - & - & 36 & Local market \\
\hline Nyanya & X & X & - & 47 & State market \\
\hline Ukpah & X & X & - & 60 & State market \\
\hline
\end{tabular}

Note:

$\begin{array}{lll}\mathrm{A} & = & \text { Market attendance within Bekwara LGA } \\ \mathrm{B} & = & \text { Market attendance outside the LGA but within the state } \\ \mathrm{C} & = & \text { Market attendance outside the state. }\end{array}$

\section{Discussion Of Major Findings}

The study has found that markets in Bekwara LGA are randomly distributed. This suggests that every place or space in the area is a potential site for market location. The markets are distributed at an average spacing of $4.3 \mathrm{~km}$. This is lower than average inter-market distance of $11.6 \mathrm{~km}$ observed in Yoruba land and medieval Europe (Hodder, 1965). Over $80 \%$ of the markets in Bekwara are located on road junctions. The other favoured site is roadside. Accessibility remain a key factors in locating markets. This finding support the view of White and Gleave that markets could be located at any point and that possible locations may include bush, junctions of path ways, hamlets and villages, on road sides or in the towns and cities [27].

The study has also revealed that the markets in the region operate a 5-day market calendar as each market holds once every five days. This periodicity regime is similar to that observed in Tiv and Idoma tribes of Benue by Smith [18].

Markets that meet the same day were found to be more widely spaced than markets that hold on adjacent market day. This support Fagerlund and Smith hypothesis, which states that proximity in space implies separation in time [19] as well as the assertion that spatial and temporal competition among periodic markets are complementary [18].

The study also revealed the existence of two market cycles or rings in the north and south of the study area. Each cycle shows the pattern of market shifts and has a number of markets. The markets centres that make up 
the northern cycle are Gakem, Ikanda, Akpakpa and Baten while those for the southern cycle include Abuochiche, Afrike II, Ukpah and Abuagbor.

Over eleven different types of commodities were traded in each market in Bekwara. The main agricultural produce for which Bekwara is known for include yams, palm wine, palm oil, palm kernel, cassava, garri, fermented cassava (Akpo), rice and groundnut. These agricultural produce are distributed to different ecological zones according to their needs. Palm oil is sent to the major regional markets in Northern Nigeria while groundnut, palm kernel, gari and pepper moved to the south.

The spheres of influence of Bekwara markets transcend local and state boundaries. However, nearly $70 \%$ of market attendance came from within Bekwara LGA, 21\% from outside the local government area but within Cross River State and $11 \%$ come from outside the state. The study revealed that over $80 \%$ of market attendants are drawn from within 50km distance. This conforms to the distance decay model of Collin Clark [28].

The study also identified three classes of markets in Bekwara. These are local, state and national markets. Local markets are Ikanda, Abuagbor and Beten markets. State markets are Akpakpa, Nyanya, Ukpah and Afrike II. National markets are Abuochiche, Gakem and Afrike 1.

\section{Conclusion}

The study of spatio-temporal distribution of rural markets in Bekwarra Local Government Area of Cross River State of Nigeria has revealed interesting features of rural markets in term of the order that exist in the distribution of of rural periodic markets in space, time and function. The study corroborated the already existing hypothesis of spatio-temporal distribution of periodic markets but distant itself from the uniform pattern of distribution of rural markets in space observed by some scholars as the markets were found to be randomly distributed. This implies that every point in the study area is a potential site for market location. Market sequence is also a major feature of the study area as two market cycles were observed in the northern and southern part of the area.

Variation in market functions were also noticed in different markets in the study area. This calls for their classification into three-local, state and national markets. This classification is based on the types of commodities offered for sale and the sphere of influence of each market. Different types of commodities were traded in Bekwarra markets but the dominant type is agricultural produce.

There is no denying of the fact that this study has added knowledge and buttress the existing ones in the literature of rural markets. Facts have also been made available for market planning and administration in the study area and elsewhere.

\section{Recommendation}

A situation where every available space in Bekwarra Local Government Area is a potential site for market location is not good for market survival and viability. This is so because every market need a threshold demand to continue performing its function as a central place for exchange of goods and services. The existence of two market cycles in a small Local Government Area like Bekwarra with a small population is not necessary for market viability. Base on these premises, this paper therefore recommends complete reorganization of rural market centers in Bekwarra Local Government Area as follows;

1 The eleven market centers in the area should be reduced to five to reflect the five market days. That will mean that the two market cycles will be reduced to one. This arrangement will enhance market viability, reduce prices of commodities and enhances government revenue collection.

2 Development of good transport network to make movement of people and commodities to and from the markets easy and at low cost.

3 State and Local Governments should collaborate with the local people to provide market facilities and services such as security, stall, packing spaces, power supply and effective market administration.

4 This work centers on the distribution of rural markets in space, time and function. Other areas of the rural markets that require further research include socio-demographic characteristics of market attendance, landuse activities around the markets, pricing system, market administration, sphere of influence of individual market and production as well as distribution of major agricultural produce in the markets.

\section{REFERENCES}

[1] Hagget, P., Cliff, A. D. and Prey, A., Locational methods(Bristol, Edward Arnold, 1977).

[2] Hodder, B. W. and Ukwu, U. I., Markets in West Africa (Ibadan, University of Ibadan Press, 1969).

[3] Omagu, D. D., History of Bekwarra people of the upper Cross River (Calabar, Achu Publisher, 1997).

[4] Christaller, W., Central places in Southern Germany (translated by C. W. Baskin) (Englewood Cliff, New Jersey, Prentice Hall, 1966).

[5] Ebong, M. O. and Animashaun, I. A., A planning perspective in rural settlement (Uyo, Kiv Publication, 1992).

[6] Hagget, P., Geography: a modern synthesis (New York, Harper and Row Publishers, 1979).

[7] Good, C. M., Periodic markets; A problem in locational analysis, The Professional Geographer, 24, 1972, $210-216$.

[8] Janet, H. R., Tropical geography (London, E. L.B. S 1977). 
[9] Hodder, B.W. and Lee, Economic Geography (London, Methuen and Co.Ltd, 1974)

[10] Stine, J. H., Temporal aspect of tertiary production element in korea, in F. R. Pitts (Ed), Urban Systems and Economic Development( Eugene, Oregon, 1962).

[11] Webber, M. J. and Symanski, R., Periodic markets: an economic location analysis, Economic Geography, 49, 1973, 213-227.

[12] Adalemo, I. A., Trader travel pattern, marketing ring and pattern of market shift, Nigerian Geographical Journal, 18, 1975, 17-26.

[13] Hodder, B. W., Rural periodic day market in parts of Yoruba land, Transaction of Institute of British Geographers,

$36,1961,97-106$.

[114] Hill, P. and Smith R. H. T., The spatial and temporal synchronization of periodic markets; evidence from four emirates in Northern Nigeria, Economic Geography, 29, 1972, 149-159.

[15] Hudson, F.S., A location theory of rural settlement, Annals Association of American Geographers, 59, 1969, $365-381$.

[16] Smith, R. H. T., West African market places; temporal periodicity and locational spacing in Meillasoux(Ed), The Development of Indigenous Trade and Markets in West Africa (London, O. U. P., 1971).

[17] Fagerlund, V. G. and Smith, R. H. T., A preliminary map of market periodicity in Ghana, Journal of Development Areas, 4, 1970, $33-48$.

[18] Wood, L. J., A spatio-temporal analysis of rural markets in Kenya, Tropical Geography, 40, 1975, 63-71.

[19] Wambugu, S. K. , A spatio-temporal analysis of periodic markets in Nyeri District, Kenya, Eastern and Southern Africa Geographical Journal, 6 (1), 1995.

[20] Udosen, C. and Adams D., A spatio-temporal synchronization of periodic markets: evidence from the hinterland of Akwa Ibom State, Global Journal of Social Sciences, 8(1), 2009, 27-37.

[21] Skinner, G. W., Marketing and social structure in rural china, Journal of Asian Studies, 24, 1964, 3-43.

[22] White, N.P. and Gleave, M.B., An economic geography of West Africa (London, Sell and Heyman, 1971). 